\title{
SPRAWOZDANIE Z DZIAŁALNOŚCI MIĘDZYWYDZIAŁOWEJ KATEDRY TEOLOGII KATOLICKIEJ UNIWERSYTETU W BIAŁYMSTOKU W ROKU AKADEMICKIM 2007/2008
}

W rok akademicki 2007/2008 Międzywydziałowa Katedra Teologii Katolickiej (MKTK) weszła z programem pracy dydaktycznej, naukowej i badawczej, wypracowanym na wcześniejszych spotkaniach roboczych. Zasadniczym celem planowanych przedsięwzięć, podobnie jak w latach ubiegłych, było promowanie nauk teologicznych w środowiskach akademickich regionu i kraju. Założenia te realizowano $\mathrm{w}$ kooperacji $\mathrm{z}$ jednostkami naukowo-badawczymi o profilu humanistycznym, filozoficznym i przyrodniczym. Konsekwentnie zatem pracownicy MKTK brali udział w konferencjach, sesjach, sympozjach i zjazdach naukowych, zazwyczaj o charakterze interdyscyplinarnym. Mając na względzie popularyzację swego dorobku w kraju i za granicą, podczas owych zjazdów dzielili się wynikami badań własnych, podejmowali dialog i brali udział w dyskusjach, zarówno na forum ogólnym publicznym, jak w węższych kręgach badaczy, niestroniących od takowegoż dialogu.

Jednym z efektów tych założeń programowych był udział MKTK, wespół z Wyższą Szkołą Administracji Publicznej im. [ks.! - T.K.] Stanisława Staszica i Towarzystwem Naukowym Warszawskim w organizacji i przebiegu II Warsztatów Filozofii Politycznej im. Stanisława Staszica pod hasłem: „Europa ducha - duch Europy" w dniach 9-10 listopada 2007 roku, które zwyczajem roku ubiegłego odbyły się w auli gmachu WSAP w Białymstoku. W założeniu organizatorów podwójna wzmianka o duchu (Duchu? - w publikacjach występuje dwojaka pisownia) wyraża intencję, by stronę materialną życia społecznego, czynniki ekonomiczne, geograficzne, technologiczne czy demograficzne rozpatrywać w ich powiązaniach ze stroną duchową, do której według formuły konferencji należy „wiara religijna, inspiracja moralna, intuicja filozoficzna, idee ustrojowe i prawne, twórcza myśl uczonych i wynalazców, natchnienia artystów”. W przesłaniu konferencji odnotowano, iż „w takim splocie kształtuje się wiekami, poczynając od świtu średniowiecza, niepowtarzalny duch (!) Europy. Niepowtarzalny, a zarazem obdarzony zalążkami uniwersalizmu, które dziś dochodzą do głosu w procesach globalizacji”. Pomimo wyraźnych niejasności w brzmieniu hasła konferencji oraz wobec braku wyjaśnienia w jego kontekście pojęcia „duch” („Duch”?), Katedra Teologii Katolickiej, nigdy niestroniąca od konfrontacji światopoglądowych, podjęła owo wyzwanie. W pierwszym dniu konferencji, w jej pierwszej części, referaty wygłosili: ks. abp prof. dr hab. Edward 
Ozorowski („Antropologia chrześcijańska w kulturze Europy”), ks. prof. dr hab Józef Zabielski („Indyferentyzm religijno-moralny jako znamię ducha współczesnej Europy”) i ks. dr Andrzej Proniewski („Czy polityka bez religii?”).

Wzorem lat ubiegłych kolejną, trzecią edycję Międzynarodowej Konferencji Naukowo-Szkoleniowej „Życiodajna śmierć”, MKTK zorganizowała wespół z Zakładem Pielęgniarstwa Ogólnego Akademii Medycznej w Białymstoku, Kliniką Neonatologii Akademii Medycznej w Białymstoku, Towarzystwem Przyjaciół Hospicjum w Białymstoku i Polskim Towarzystwem Lekarskim Oddział Regionalny Białystok. Obrady trwały w dniach 6-9 grudnia 2007 roku w Aula Magna Akademii Medycznej w Białymstoku. Konferencja, w ogólnych założeniach rozumiana jako miejsce refleksji nad społecznymi, moralnymi i kulturowymi aspektami rozumienia śmierci we współczesnym świecie, tym razem poświęcona była głównie zagadnieniu śmierci dziecka. Spośród pracowników Katedry podczas obrad referaty wygłosili ks. prof. dr hab. J. Zabielski i ks. dr hab. A. Skreczko. Swoje wystąpienie ks. Zabielski osnuł wokół stwierdzenia, iż „wartościowanie życia wiecznością oznacza odkrywanie życia”, dlatego też bardziej niż śmierci należy obawiać się niespełnionego życia. Refleksja nad życiem jest potrzebna zwłaszcza w kontekście współczesnej kultury, gdzie niejako skraca się perspektywę życia, zacieśniając je tylko do sfery zmysłowo-poznawczej. Ksiądz Skreczko w referacie „Dziecko wobec śmierci bliskiej osoby” wskazał na konieczność dostrzegania uczuć dziecka i poważne ich traktowanie. Najważniejsze jest tu - jego zdaniem - osobiste świadectwo rodziców i osób bliskich: „Jeżeli rodzice oraz dorośli otaczający dziecko akceptują swoją śmiertelność, przyznają się do własnych ograniczeń, swojej bezsilności wobec śmierci, a jednocześnie mają poczucie sensu życia i śmierci - to dzieci akceptują fakt, że śmierć jest integralną częścią życia”. Podczas czterodniowej konferencji poruszano szerokie spektrum zagadnień, wśród których znalazły się tematy dotyczące między innymi aspektów medycznych i prawnych śmierci mózgu, ciąży obumarłej, czy eutanazji. Poruszono też problematykę motywów śmierci w sztuce, czy wykorzystanie wartościowej literatury dziecięcej w opiece nad dziećmi nieuleczalnie chorymi.

„Bądźcie uczniami Moimi” - to hasło konferencji naukowej zorganizowanej przez MKTK 12 stycznia 2008 roku. Obrady odbywały się w sali kina „Ton” w Białymstoku. Ponieważ konferencja była centralnym punktem dorocznego spotkania duchownych i katechetów archidiecezji białostockiej, zwyczajowo zwanym „zjazdem kolędowym”, celem obrad było bliższe zapoznanie i pogłębienie treści zawartych $\mathrm{w}$ programie duszpasterskim na dany rok liturgiczny. We wprowadzeniu do obrad ks. abp E. Ozorowski przypomniał, iż „tematem tego spotkania jest pytanie, jak dzisiaj być uczniem Chrystusa pojedynczo i we wspólnocie. Jest to zadanie do stałego rozważania, ponieważ posiadać można jedynie zdobywając". W kontekście tego stwierdzenia swoimi przemyśleniami 
zawartymi w referatach podzielili się ks. abp prof. dr hab. Stanisław Gądecki, metropolita poznański oraz ks. dr Joachim Waloszek - rektor Wyższego Seminarium Duchownego w Opolu i adiunkt przy Zakładzie Muzyki Kościelnej i Wychowania Muzycznego Wydziału Teologicznego Uniwersytetu Opolskiego. W referacie pt. „Teologia uczniostwa” abp Gądecki wskazał na trudności związane z przechodzeniem od religijności do wiary żywej. W tym procesie i jego zwieńczeniu zawiera się temat „bycia uczniem Chrystusa”. Jego zdaniem "być uczniem Chrystusa we współczesnym świecie jest zadaniem trudnym ze względu na wewnętrzne rozbicie człowieka i „kontrkulturę”, która często przeciwstawia się chrześcijaństwu”. Ksiądz Waloszek, referując temat "Co znaczy być uczniem Chrystusa dziš”, stwierdził wyraźnie, iż tej postawy „nie można nauczyć się raz na zawsze, wyposażając się w system wartości, ocen, osądów moralnych, który wystarczy potem konsekwentnie stosować w życiu”. Szkoła Chrystusa - mówił - jest pomyślana zupełnie inaczej: „to uczestnictwo w żywej, ciągle aktualnej historii Wcielonego Słowa, w historii skomponowanej z nieprzewidywalnych wydarzeń, spotkań, dziejących się $\mathrm{w}$ tym świecie mocą Ducha Bożego. Jest niekończącą się przygodą, dramatem, jakąś wyprawą w nieznane, choć z pewną nadzieją na osiągnięcie celu”. Do pytania postawionego w tytule referatu prelegent nawiązał w konkluzji swego wystąpienia: „chciałoby się w jakiejś jednej, prostej formule zmieścić całą mądrość zebraną w tradycji chrześcijańskiej duchowości i pedagogii Kościoła. Pan Jezus mówi po prostu: „pójdź za Mną” - zakończył.

Słowami: „Jeśli ludzie odczytają nawiedzenie Obrazu Jezusa Miłosiernego, to myślę, że coś się w nich zmieni, że zaczną topnieć lody i tam, gdzie dotąd były ciężkie chmury pojawi się słońce" - ks. abp E. Ozorowski rozpoczął konferencję pod hasłem „Liturgia życiem Kościoła”, zorganizowaną wysiłkiem MKTK i Kurii Metropolitalnej Białostockiej w dniu 29 marca 2008 roku w ramach dorocznego tzw. „Zjazdu Paschalnego” duchownych i katechetów Archidiecezji. Obrady odbyły się w sali kina „Ton” w Białymstoku. W założeniu organizatorów konferencja stanowiła istotny element przygotowania do peregrynacji Obrazu Jezusa Miłosiernego po parafiach archidiecezji białostockiej, a w dalszej perspektywie - przygotowania do beatyfikacji Sługi Bożego, ks. Michała Sopoćki. W tym kontekście ks. Arcybiskup przypomniał, że nawiedzenie Obrazu domaga się odnowy także $\mathrm{w}$ sferze celebrowania liturgii, stąd taka, a nie inna tematyka konferencji. Problematykę poprawnej celebracji liturgii podjęli w swych wystąpieniach wykładowcy Archidiecezjalnego Wyższego Seminarium Duchownego w Białymstoku: ks. dr Tomasz Powichrowski i ks. mgr Krzysztof Łapiński. Wygłosili oni referaty pod wspólnym tytułem „Zachwaszczenia liturgii w archidiecezji białostockiej”. Ksiądz Powichrowski, liturgista z wykształcenia, wprowadzając w zasadniczą problematykę swego wystąpienia, przypomniał, że „wartość i piękno liturgii polega między innymi na posłuszeństwie obowią- 
zującym w Kościele zasadom celebracji, która to postawa posłuszeństwa jest uwarunkowana faktem, iż liturgia jest dziełem Chrystusa i Kościoła, a nie prywatnych osób”. Prelegent omówił następnie poszczególne części liturgii mszalnej i pozamszalnej, wskazując na mogące ewentualnie pojawić się nieprawidłowości i niekonsekwencje w jej sprawowaniu. Ksiądz Łapiński natomiast wskazał na miejsce śpiewu i muzyki w liturgii oraz omówił pokrótce najczęściej pojawiające się w tym względzie błędne uproszczenia i niekonsekwencje. W drugiej części konferencji ks. mgr Roman Balunowski, dyrektor Wydziału Duszpasterstwa Kurii Metropolitalnej Białostockiej, podał do wiadomości program nawiedzenia obrazu Jezusa Miłosiernego i wskazał na sposób przygotowania parafian do tego wydarzenia. Ksiądz Arcybiskup w dłuższym wystąpieniu nawiązując do powyższego, wskazał na obraz Jezusa Miłosiernego jako na zadanie, które trzeba odczytać. Stwierdził: „Jest to zadanie, aby to co plastycznie malarze przedstawili, starając się wyrazić pragnienie samego Jezusa Chrystusa, teraz to przenosić na nasz umysł i serce, aby obraz był dla nas przezroczystą szybą, za którą widzimy inny świat - nadprzyrodzony, czyli Jezusa, który stał się dla nas przejawem Bożego Miłosierdzia”. Wspólną modlitwą, poprowadzoną przez ks. Arcybiskupa, zakończono obrady.

Wspólnym wysiłkiem Katedry Teologii Katolickiej i Wyższej Szkoły Ekonomicznej w Białymstoku, w ramach stałej współpracy tych jednostek naukowo-dydaktycznych, doszła do skutku zaplanowana już w roku ubiegłym ogólnopolska konferencja naukowa zorganizowana pod hasłem „Kobieta - etyka - ekonomia”. Obrady odbyły się w dniach 15-17 września 2008 roku w sali konferencyjnej hotelu „Wojciech” w miejscowości Wojciech k. Augustowa. Tegoroczna konferencja była kolejną z cyklu - piątą już - której uczestnicy w perspektywie etyki i ekonomii podjęli ważne tematy z zakresu życia ludzkiego. Intencją tegorocznej konferencji było zwrócenie uwagi na kobietę w kontekście społecznym, etycznym i ekonomicznym. Uczestnicy konferencji objęli szeroki zakres problemów, co umożliwiło zebranie cennych opinii i poglądów na temat uczestnictwa kobiet w życiu zawodowym i publicznym, biznesie i polityce. W ramach tegorocznej konferencji wygłoszono 25 referatów. Wyniki swych badań prezentowali przedstawiciele nauk społecznych, ekonomicznych, teologicznych i filozoficznych z kilku ośrodków naukowych Białegostoku, Warszawy, Łodzi, Wrocławia i Poznania. Pięć referatów, dzieląc się rezultatami swych naukowych dociekań, zaprezentowali pracownicy MKTK: ks. abp E. Ozorowski („Geniusz kobiety według Jana Pawła II”), ks. J. Zabielski („Wspólnototwórcza rola kobiety”), ks. A. Proniewski („Feminizm z punktu widzenia teologii”), ks. A. Skreczko („Kobieta jako wychowawczyni”) i ks. T. Kasabuła („Pozycja społeczna kobiety na ziemiach polskich w XIX wieku”). Teksty tych i wszystkich pozostałych wystąpień zostaną opublikowane, wzorem lat ubiegłych, w osobnej pozycji książkowej. Kończąc i podsumowując konferencję ks. Arcybiskup 
wyraził przekonanie, że wypracowane wnioski przyczynią się do upowszechnienia rzeczywistego spojrzenia na kobietę. Środowiska naukowe, otwarte na zmiany, zobowiązane są bowiem do troski o obalanie stereotypów i głoszenie prawdy o współistnieniu, współwspieraniu i uzupełnianiu się obojga płci bez wyróżniania i prawa do hierarchizowania.

Wyrazem uznania względem kierownika Katedry Teologii Katolickiej ze strony władz Uniwersytetu w Białymstoku było nadanie ks. abp. Edwardowi Ozorowskiemu doktoratu honoris causa tejże uczelni. Akt ten miał miejsce 1 października 2007 roku podczas uroczystości inauguracji roku akademickiego 2007/2008 w auli Wydziału Prawa UwB. W laudacji, którą wygłosił rektor Uniwersytetu w Białymstoku, prof. dr hab. Jerzy Nikitorowicz, zgodnie z tradycyjną procedurą znalazło się uzasadnienie tej decyzji. Rektor ogłosił mianowicie, iż honorowy tytuł naukowy ks. Arcybiskup otrzymał za krzewienie myśli teologicznej w środowisku akademickim, propagowanie dialogu ekumenicznego i szacunku dla wszystkich kultur, obronę godności osoby ludzkiej, małżeństwa, rodziny oraz za pracę nad szerzeniem postawy tolerancji. W uroczystości, obok rektora i senatu białostockiej Alma Mater, udział wzięli rektorzy wyższych uczelni Białegostoku i innych polskich wyższych uczelni, przedstawiciele władz państwowych i samorządowych, abp Stanisław Szymecki, duchowni archidiecezji oraz hierarchowie Kościoła prawosławnego: abp metropolita Warszawy i całej Polski Sawa i bp białostocko-gdański Jakub. Ksiądz Arcybiskup stwierdził, że w przyjęciu doktoratu honoris causa widzi wyróżnienie będące postulatem, kim bardziej być powinien, aniżeli informację o tym kim jest. „Widzę w tym wyróżnieniu - powiedział - środowisko, w którym się urodziłem, moją ziemię rodzinną, szkoły i uczelnie, przez które przeszedłem dotąd, oraz środowisko, do którego należę”. W wykładzie inauguracyjnym pt. „Nauka a pytania graniczne" zauważył między innymi, że skuteczność prowadzonych badań zależy od umiejętności stawiania pytań i uczciwości w dawaniu na nie odpowiedzi". „Taka postawa - kontynuował - jest nie tylko warunkiem rozwoju nauki, ale warunkiem istnienia świata i człowieka”.

Pewną formą uznania dla aktywności Katedry na forum uniwersyteckim było przyznanie 10 października 2007 roku Nagrody Rektora Uniwersytetu w Białymstoku „za pracę naukową i działalność organizacyjną” adiunktom MKTK: ks. dr. Tadeuszowi Kasabule i ks. dr. Andrzejowi Proniewskiemu.

Pracownicy MKTK realizowali przewidzianą statutem działalność dydaktyczną prowadząc wykłady, głównie monograficzne, konwersatoria i ćwiczenia na poszczególnych wydziałach UwB. Ponadto realizując badania własne brali udział w konferencjach, sympozjach, sesjach i zjazdach naukowych, prezentując tam $\mathrm{w}$ formie referatów i dyskusji wyniki swych naukowych dociekań. Wnosili tym samym wkład w rozwój tych dziedzin, które stanowią obszar ich zainteresowań. Wymiernym i widocznym wynikiem ich aktywności naukowo-badawczej są 
publikacje. Spośród nich warto zauważyć pozycje książkowe autorstwa pracowników MKTK, przez nich redagowane lub współredagowane. W minionym roku akademickim ukazały się zatem następujące publikacje książkowe: J. Zabielski, Wrastanie w życiowym powotaniu (Białystok 2008), A. Skreczko, B. Grużewski, Nauczanie religii i postawy katechetów Wileńszczyzny (Białystok 2008), Spis kościotów i duchowieństwa Archidiecezji Biatostockiej, red. A. Skreczko (Białystok 2008), Mój Kościót whistorię wpisany, współred. T. Kasabuła (Białystok 2007), X lat Uniwersytetu w Biatymstoku 1997-2007, współred. T. Kasabuła (Białystok 2008). Wykaz pozostałych publikacji w formie artykułów naukowych i popularnonaukowych jest na bieżąco zamieszczany na stronie internetowej Katedry (www.ktk.uwb.edu. pl) oraz w wykazie publikacji wykładowców AWSD w Białymstoku, zamieszczanym co roku w kwartalniku Kurii Metropolitalnej Białostockiej („Wiadomości Kościelne Archidiecezji Białostockiej”, 36:2008, nr 4).

W ramach działalności publicystyczno-wydawniczej zespół redakcyjny złożony z pracowników MKTK przygotował do druku i wydał w listopadzie 2007 roku kolejny, szósty tom czasopisma Katedry pt. „Rocznik Teologii Katolickiej”. W chwili obecnej na ukończeniu są prace nad tomem siódmym.

Regularne spotkania robocze przygotowywane przez kierownika Katedry i przezeń prowadzone służą podsumowaniu dotychczasowej działalności, opracowywaniu projektów prac badawczych, omawianiu nowych inicjatyw oraz koordynacji badań własnych i statutowych pracowników MKTK. Owoce tych ustaleń przybierają realny kształt w postaci organizowanych przez Katedrę konferencji naukowych, popularyzujących wiedzę teologiczną w regionie i w kraju.

Ks. Tadeusz Kasabuta 